\title{
О ДЕЯТЕЛЬНОСТИ «ДИКИХ» АРТЕЛЕЙ В ИРКУТСКОЙ ГУБЕРНИИ ВО ВТОРОЙ ПОЛОВИНЕ 1920-х ГОДОВ
}

\begin{abstract}
Анализируются социально-экономические особенности развития Иркутской губернии в условиях нэпа, которые привели к оживлению частного предпринимательства и появлению «диких» артелей; а также политика руководства, направленная на вытеснение частного производителя из мелкой и кустарно-ремесленной промышленности.

Ключевые слова: промысловая кооперация, товарищество, артель, промысловый союз, кустарь, ремесленник.
\end{abstract}

S.A. SEMINA

\section{ON THE ACTIVITIES OF THE «SPONTANEOUS» COOPERATIVES IN IRKUTSK PROVINCE IN THE SECOND HALF OF THE 1920s}

The article analyzes the socio-economic features of the development of the Irkutsk province in the conditions of New Economic Policy, which led to the revival of private entrepreneurship and the emergence of «spontaneous» cooperatives; as well as management policy aimed at displacing private producers from the small and handicraft industry.

Keywords: trade cooperation, partnership, cooperative, trade union, handicraftsman, craftsman. 
В годы нэпа экономическая политика государства строилась на признании рыночных отношений. Провозглашение одного из компонентов рыночной экономики - свободного обмена, способствовало активизации торговых отношений, к которым неизбежно привлекались государственные и кооперативные объединения. Легализация товарно-денежных механизмов неизбежно влекла за собой сложную сеть взаимоотношений между отдельными кустарями, кооперативными артелями и государственными организациями.

Развитию торговли способствовало снятие еще в 1922 г. запрета на открытие ярмарок. В связи с этим, к концу 1923 г. потребление продукции кустарей и ремесленников увеличилось до 80 \%, на товары промышленного производства спрос достигал 20 \%. Особенно ощутимо это стало проявляться в период назревания «кризиса сбыта», когда изделия, произведенные в городе, не находили своих основных потребителей, сельских жителей. Найти покупателя для промышленных товаров могла только кооперация.

В 1925 г. на территории Иркутской губернии был образован губернский промыслово-кооперативный союз охотников, а также промысловый союз рыбацких и интегральных кооперативов, который занимался снабжением рыбаков принадлежностями ловли, арендой рыболовных угодий и их охраной. А в 1926 г. возник Иркутский кооперативный кустарно-промысловый союз (Ирпромсоюз). Одним из направлений деятельности промсоюзов было кооперирование кустарей и ремесленников периферии. Именно на этом этапе возникал ряд трудностей.

Слабая связь кооперации с местным рынком, отсутствие государственного снабжения и сбыта, совершенно недостаточное участие потребителя в работе кооперации, чрезмерная дороговизна и неудачный подбор товаров давали преимущества частной торговле. Огромное преобладание, особенно в городах, частной торговли было преобладающим - более $80 \%$.

Таблица 1

Соотношение отдельных видов торговли за 1925-1926 гг., \%

\begin{tabular}{|l|r|r|r|}
\hline \multicolumn{1}{|c|}{ Расположение предприятий } & \multicolumn{3}{|c|}{ Торговля } \\
\cline { 2 - 5 } & государственная & кооперативная & частная \\
\hline В г. Иркутске из 1367 предприятий & 7,0 & 3,5 & 89,5 \\
\hline В прочих городах губернии из 794 заведений & 5,5 & 12,2 & 82,3 \\
\hline В сельской местности из 1050 предприятий & 9,0 & 38,0 & 53,0 \\
\hline
\end{tabular}

Составлено по: 1, оп. 1, д. 782, л. 2.

Основной базой для приобретения сырья многих кустарно-промысловых артелей также являлся местный рынок, т.е. сырье приобреталось не по генеральным договорам с заготовителями, а по сделкам с частными торговцами. 
Финансовая слабость промысловых кооперативов на первых порах приводила к зависимости от частного скупщика и вынуждала прибегать к его посредничеству. Например, в 1925 г. всего 19,32 \% кооперативов сбывали свою продукцию через Ирпромсоюз, через прочие конторы 41,4 \% [1, оп. 1, д. 781, л. 28 об.]. Большинство торговых предприятий деревни находились в руках частных владельцев, что говорило об организационной слабости зарождающейся кооперации.

Таким образом, потребитель продуктов кустарного производства был почти всегда известен - это заказчик, он же являлся и поставщиком материала. Стоимость продукции таких кустарей на 80 \% определялась стоимостью сырья заказчика и на 20 \% заработком кустаря [8, с. 96].

Появление частников-скупщиков привело к широкому распространению системы квартирничества - раздачи кустарям заказов на дом и организации фиктивных артелей в целях получения налоговых льгот. Частник, получая в финансовом отделе патент 1-го разряда (как не имеющий, кроме двух-трех подростков, наемной рабочей силы), в то же время организовывал производство экономически зависимых от него кустарей-одиночек. Все они фактически являлись наемными рабочими, работали по заказу хозяина, его инструментом, использовали его сырье. Он же организовывал сбыт продукции, сосредотачивал у себя продукцию других, хотя и менее зависимых от него, но экономически слабых одиночек. Вывеска кустаря нужна была такому предпринимателю не только для получения высокой прибыли, но и для уклонения от уплаты налогов и соблюдения трудового законодательства.

Как известно, в отношении зажиточных слоев населения в первые годы нэпа политика государства строилась на предоставлении им некоторых экономических свобод. Однако во второй половине 1920-х гг. решающим направлением становится постепенное изживание этой социальной верхушки. В первую очередь власти решили ущемить их положение в области налогового законодательства. Так, налоговая политика Иркутской губернии в 1925-1926 гг. была направлена на сокращение зажиточных хозяйств. Размер сельскохозяйственного налога для кулаков был в 17,5 раза выше, чем у бедняков. В отношении частного кустарного производства правительство также шло на всевозможные поборы. Размеры изъятий нетрудовых доходов в частных предприятиях за 1926-1927 гг. составляли с 30 до 45 \%. Несколько ранее был увеличен промысловый налог, который в среднем был в 2-2,4 раза выше для частных предприятий по сравнению с государственными и кооперативными [1, оп. 1, д. 781, л. 35].

Преимущества в выдаче заказов, обеспечении сырьем, аренде помещений, организации сбытовых операций давали возможность многим частным предпринимателям выдавать свою деятельность за кооперативную. Например, под вывеской кооперативной артели скрывались частные предприниматели пимокатной артели «Волга», а бывший вла- 
делец фабрики Комаров стал ее председателем. Он сдал в аренду свой инвентарь, пустил в ход свой капитал. Рабочий день в артели длился 14 часов, отсутствовала охрана труда [7]. Рютинская артель по производству кожевенных изделий также состояла из членов одной семьи во главе с Копылевичем, он же являлся владельцем кожевенного завода при артели [2, оп. 1, д. 359, л. 2].

Частные предприниматели, организуя артель, не спешили входить в промысловый союз. Основная масса вовлеченных в кооперирование кустарей была заинтересована только в приобретении сырья от союза, а сбытовые и производственные операции предпочитала вести самостоятельно. Например, в 1925 г. промысловая кооперация губернии объединяла 15 \% кооперативов, а 451 артель не входила в систему союзов, предпочитая вести частную производственную деятельность [9, с. 131]. Для многих из них промысловый союз являлся ограничением хозяйственных и экономических свобод.

Владельцам мелких частных предприятий предстояло сделать выбор: либо за широкий набор услуг производить отчисления в пользу промысловых союзов, либо вместо этих отчислений на свой страх и риск производить сбыто-снабженческие операции, получая максимальную прибыль или терпя финансовый крах. Такие артели относились к категории «диких». Их организовывали бывшие предприниматели и торговцы. Формы их участия в деятельности промысловых артелей были очень разнообразными. Часть из них под видом кооперативной артели продолжала вести частную производственную деятельность, другие занимались сдачей в аренду под большие проценты оборудования, помещений и средств производства, участвуя в снабжении и посредничестве сбытовых операций. Личное участие таких предпринимателей выражалось в осуществлении ими функций руководителей и администраторов артелей.

Так, в докладе инструктора потребительской кооперации Ирсоюза О.Е. Красницкого «О положении кустарно-промысловых и сельскохозяйственных артелей Балаганского района Иргубсоюза» отмечалось, что многие из обследованных артелей не имели устава, следовательно, не были зарегистрированы. Большинство из них не вели фринансовой отчетности, в результате чего было сложно судить об их торговой и производственной деятельности. К таким артелям относилась Яндинская трудовая артель мыловаров. Она не вела отчетности, не имела устава и не была включена в список подлежащих обследованию артелей [2, оп. 1, д. 359, л. 1].

В 1927 г. Иркутским отделением Рабоче-крестьянской инспекции было проведено обследование 15 из 22 кустарно-промысловых артелей. Оно показало, что в 6 из них председателями являлись бывшие торговцы, в 5 они входили в состав правлений и фактически руководили ими, так как владели основной частью средств производства [1, оп. 1, д. 781, 
л. 28, 36]. Так, Быстров до 1926 г. имел собственную хорошо оборудованную конфетную фрабрику. В результате начала работы государственной конфетной фабрики и усиления налогового нажима был вынужден закрыть предприятие. Через некоторое время Быстров организовал кооперативную артель «Пищевкус». В правление артели кроме него входила его жена, частники Василенко с женой и Стародумов [5, оп. 1, д. 1072, л. 54]. В кооперативной артели «Карамельщик» предприниматели Кац, Фромберг сдавали в эксплуатацию за определенный процент свои машины и инвентарь. Когда артель испытывала фринансовые трудности, Фромберг давал артели крупные суммы денег. Так же обстояло дело и в других обследованных артелях — «Кондитер», «Пряничник», «Трикотажник».

Также, проведенными ревизионными обследованиями установлено, что в Иркутском округе на 1 июля 1927 г. из всех существовавших кустарно-промысловых артелей 41,3 \% являлись «дикими» [1, оп. 1, д. 781, л. 28,$36 ; 4$, оп. 1, д. 201, л. 173].

В отношении производственного кооперирования многие владельцы кустарно-промышленных заведений предпочитали занимать выжидательную позицию или же участвовать в кустарно-кредитной кооперации. Здесь им представлялись возможности организации свободного сбыто-обмена. Однако часто в таких артелях не соблюдались кооперативные принципы работы.

Ярким примером подобной деятельности служит Зиминское кустарное кредитное товарищество, образованное в 1928 г. В его состав из 200 членов входило 148 кустарей-одиночек и всего 10 самостоятельных артелей [5, оп. 1, д. 1072, л. 126]. Товарищество имело собственные производства и кузницу. Акты обследований товарищества обнаружили несколько нарушений. Общих собраний оно не вело, протоколы составлялись только председателем правления Патокиным и членом правления Ляпуновым (он же и бухгалтер). Члены артелей Зиминского товарищества совершенно не были знакомы с принципами, целями и задачами организации промысловых артелей. Многие из них не имели понятия о регистрации, страховании, твердых ценах на свои товары. Продукцию зачастую сдавали на рынок или местным потребителям на заказ [5, оп. 1, д. 1072, л. 137].

Таким образом, основная масса кустарей-одиночек и ремесленников губернии не спешила связывать отношения с промысловой кооперацией. Отчасти объяснялось это исторически сложившейся значимостью кустарно-промысловой деятельности в экономической жизни региона, спецификой ряда производств, исключающих возможность кооперативного объединения, менталитетом кустарей и т.п.

Зависимость заготовительных операций кустарной промышленности от частных лиц также сильно осложняла объединение промысловиков. В 1927 г. в Иркутской губернии более 70 \% кустарей оставались вне 
кооперирования. Однако «гонения» на частное производство и зажиточные хозяйства, а также система мер, направленная на стимулирование именно кооперативной, легальной деятельности привели к сокращению удельного веса «диких» артелей губернии в 1928 г. до 22,6 \%, а количество занятых в них лиц уменьшилось почти в 11 раз (с 636 до 50 человек) [4, оп. 1, д. 201, л. 173]. На 1928 г. было зарегистрировано 168 промысловых артелей, из них ликвидировано 35, среди которых 27 были отнесены к категории «диких» [3, оп. 1, д. 235, л. 3]. К 1930 г. влияние промыслового союза распространялось на 40,8 \% некооперированных предприятий кустарей, работающих на заказ и на сырье скупщиков. Все они оказались связанными с промысловой кооперацией [6, с. 13].

Таким образом, с утверждением нэпа государство лишь ослабило, но не прекратило регулирование хозяйственно-экономических процессов в стране. Временное восстановление посреднических и торговых фрункций в области производственного кооперирования параллельно дополнялось внедрением системы государственного планирования и контроля над хозяйственной деятельностью предприятий и кооперативов разного уровня. Пристальное внимание центральные кооперативные органы обращали на «дикие» артели и лжекооперативы. В целях пресечения лжекооперативной деятельности начали широко практиковаться ревизии социального состава кооперативов. Фиктивными или некооперативными стали считаться не только те, которые были связаны с частным капиталом и возглавлялись бывшими хозяевами, но и те, которые искусственно устанавливали вступительный пай. Систематические проверки социального состава артелей способствовали постепенному вытеснению частного производителя из мелкой и кустарно-ремесленной промышленности.

Близилось завершение нэпа, усиливалось вмешательство государства во внутренние дела кооперативов. Страна вступила в стадию ускоренной индустриализации. В конце 1920-х гг. правительством был принят курс на массовое кооперирование кустарей и ремесленников с преимущественным производственным уклоном.

\section{Список использованной литературы и источников}

1. Государственный архив Иркутской области (ГАИО). - Ф. p-11 (Фонд Иркутской губернской рабоче-крестьянской инспекции и ее уполномоченных по уездам. 1920-1926 гг.).

2. ГАИО - Ф. p-312 (Фонд Иркутского окружного отдела местного хозяйства. 1926-1930 гг.).

3. ГАИО. - Ф. p-222 (Фонд Иркутского губернского союза кооперативов («Иргубсоюз»). 1916-1930 гг.)

4. ГАИО. - Ф. p-836 (Фонд Иркутского окружного отделения Наркомата Рабоче-крестьянской инспекции. 1927-1930 гг.) - Оп. 1 - Д. 201.

5. Государственный архив новейшей истории Иркутской области. - Ф. p-16 (Фонд Иркутского окружного комитета ВКП(б). 1926-1930 гг.) 
6. Вильрат В. Г. Мелкая промышленность 13 районов Восточно-Сибирского края / В. Г. Вильрат, Г. Н. Дробышева. - Иркутск, 1930. - 104 с.

7. Власть труда. - 1927. - 12 июня.

8. Соколов М. П. Сельские кустари Восточно-Сибирских округов (по обследованию 1925 г.) / М. П. Соколов, А. Т. Самохин. - Иркутск, 1927. - 122 с.

9. Угроватов А. Г. Промысловая кооперация в 20-е годы / А. Г. Угроватов // ЭКО. - 1993. — № 2. - С. 126-137.

\section{Информация об авторе}

Семина Снежана Александровна — кандидат исторических наук, доцент, заведующий кафедрой теории и истории государства и права, Восточно-Сибирский институт экономики и права, 664057, г. Иркутск, ул. Байкальская, 258a; e-mail: snezh-kaSem@yandex.ru

\section{Author}

Shezhana A. Semina - PhD in History, Associate Professor, Head of the Department of Theory and History of State and Law, East-Siberian Economics and Law Institute, 258a Baikalskaya St., 664057, Irkutsk, Russia; e-mail: snezh-kaSem@yandex.ru 